Zhanna Amangeldinovna Khamzina*

Yermek Buribayev":

Kuralay Turlykhankyzy*:*:*

Zhanar Moldakhmetova

Bakhytkali Koshpenbetov $* * ; * ;$

Kalkayeva Nessibeli"

\title{
UNLOADING THE JUDICIAL SYSTEM IN KAZAKHSTAN? ALTERNATIVE WAYS OF RESOLVING INDIVIDUAL LABOUR DISPUTES
}

* Doctor of Juridical Science, Professor at the Department of Law, Abai Kazakh National Pedagogical University, 13 Dostyk Ave., Almaty, 050000, Kazakhstan; https:// orcid.org/0000-0003-0913-2002; e-mail: 292803@mail.ru.

** Doctor of Juridical Science, Professor at the Department of Law, Abai Kazakh National Pedagogical University, 13 Dostyk Ave., Almaty, 050000, Kazakhstan; https:// orcid.org/0000-0003-2631-6372; e-mail: yermek-a@mail.ru.

*** PhD Candidate in Jurisprudence, Abai Kazakh National Pedagogical University, 13 Dostyk Ave., Almaty, 050000, Kazakhstan; e-mail: kuralay_turlykhan@mail.ru.

**** Senior Lecturer at the Department of Law, Abai Kazakh National Pedagogical University, 13 Dostyk Ave., Almaty, 050000, Kazakhstan; https://orcid.org/0000-00027024-5498; e-mail: moldaxmetova_zh@mail.ru.

***** PhD Candidate in Jurisprudence, Associate Professor at the Department of Law, Abai Kazakh National Pedagogical University, 13 Dostyk Ave., Almaty, 050000, Kazakhstan; https://orcid.org/0000-0001-5054-6560; e-mail: kbakitkali@mail.ru.

$* * * * * *$ PhD Candidate in Jurisprudence, Associate Professor at the Department of Law, Abai Kazakh National Pedagogical University, 13 Dostyk Ave., Almaty, 050000, Kazakhstan. 


\section{Abstract}

The purpose of the study is to develop proposals for the modernization of the judicial form of protection of social and labour rights and interests of the individual. We are testing the hypothesis about the priority and universality of the judicial form of protection of rights in relation to other ways of applying for the restoration of violated labour interests; we assess access to justice as a criterion for the effectiveness of the judicial form of protection. The main method is a desk study of law enforcement practice, reports related to the functioning in Kazakhstan of a judicial form of protection of the social and labour rights of an individual, also the method of analysis of documents and statistical data of courts, a survey of examples of the best foreign practice in the work of specialized courts, and an analysis of international universal standards of access to justice in social and labour disputes.

\section{Keywords}

workplace conflict - labour relations - legal regulation - labour law - judicial system

\section{INTODUCTION}

The reforms of the Kazakhstan labour market that have taken place over the past five years were initiated to solve the problems of defining the boundaries of state intervention in the sphere of labour relations between employers and employees, the distribution of their roles and responsibilities, as well as the introduction of the principle of self-regulation in labour relations, with the strengthening of the potential of collective bargaining and agreements in such areas as hiring, personnel movement, and the dismissal of employees, working hours, conditions, and remuneration of their labour. The liberalization was designed to find a new balance between the flexibility desired by business and the required social protection of workers, and to bring the law in line with modern changes in the field of labour. The 2016 Labour Code of Kazakhstan was supposed to modernize labour relations in a much broader perspective - to revive the spirit of cooperation at both the individual and collective level, and to strengthen the judicial protection of employees to ensure greater recognition of the importance of investing in human capital and respect for the employee's personality and family obligations. Despite the liberalization carried out and the improvement in 
the quality of legal support for human labour rights, regulation in this area is not without several shortcomings: the percentage of labour disputes is still high, and no real mechanisms have been created to prevent collective and individual conflicts that give rise to dangerous social confrontations.

The issues of the practice of resolving labour disputes were not the object of a comprehensive study of the Kazakhstani jurisprudence. If the judicial procedure for resolving labour conflicts in the national science of labour law and social security law has been studied in limited publications, ${ }^{1}$ then in foreign science the possibilities of alternative methods of resolving labour disputes, ${ }^{2}$ assessing the effectiveness of the judicial form of protection of labour rights, ${ }^{3}$ dispute resolution systems

${ }^{1}$ A. Issayeva, B. Aitimov, Z. Issayeva, M. Zhussupbekova, S. Tinistanova, A. Madaliyeva, "Features of legal regulation of the procedure for the consideration of labour disputes in Kazakhstan", Journal of Advanced Research in Law and Economics, 2020, Issue 11, pp. 1-73; G. Galiakbarova, S. Zharkenova, L. Kulmakhanova, "Revisiting jurisdiction of individual labour disputes in the republic of Kazakhstan: Comparative legal analysis of the labour law application in countries near and far abroad", Journal of Advanced Research in Law and Economics, 2016, Issue 7, pp. 64-74; Z. Khamzina, Y. Buribayev, P. Almaganbetov, A. Tazhmagambet, Z. Samaldykova, N. Apakhayev, "Labour disputes in Kazakhstan: Results of legal regulation and future prospects", Journal of Legal, Ethical and Regulatory, 2020, Issue, 23, pp. 1-14.

2 A. J. S. Colvin, "American workplace dispute resolution in the individual rights era", International Journal of Human Resource Management, 2012, Issue 23, pp. 459-475; B. Freyens, X. Gong, "Judicial arbitration of unfair dismissal cases: The role of peer effects", International Review of Law and Economics, 2020, Issue 64; C. A. López, B. Y. J. Giraud, "Decongestion of the judicial system in Ecuador. Alternative dispute resolution method in mediation in the first instance in labour matters", Universidad y Sociedad, 2020, Issue 12, pp. 518-524; I. Erceg Ćurić, D. Pivčević, “Court disputes arising due to the violation of workers' rights to occupational health and safety and safe working conditions", Sigurnost, 2020, Issue 62, pp. 93-103.

3 S. Corby, R. Yamakawa, “Judicial regimes for employment rights disputes: Comparing Germany, Great Britain and Japan”, Industrial Relations Journal, 2020, Issue 51, pp. 374-390; O. Boieva, "Institute of legal protection of labour rights in Ukraine: Genesis and current state", Humanities and Social Sciences Reviews, 2019, Issue 7, pp. 777-781; R. Jagtenberg, A. de Roo, "Employment disputes and arbitration, an account of irreconcilability, with reference to the EU and the USA", Zbornik Pravno Fakulteta u Zagrebu, 2018, Issue 68, pp. 171-192; N. Hosogaya, "Individual labor-related dispute mechanisms in Japan-Policy intention and individual worker aspirations", Creating social cohesion in an interdependent world: Experiences of Australia and Japan, 2016, pp. 221-241; S. Jefferys, “Collective and individual conflicts in five European countries", Employee Relations, 2011, 
on social security, ${ }^{4}$ the influence of representatives on effective dispute resolution ${ }^{5}$ have been studied extensively, but mainly concerning national legal conditions and institutions.

In Kazakhstani legal science, there are no special studies the subject of which would be materials of judicial practice on labour disputes. From this position, the co-authors of this article obtained from official open information databases extensive data on labour conflicts considered by the courts, which were critically analyzed and systematized to form a reliable baseline for research. In Kazakhstan, information on litigation (for the most part) is freely available.

\section{Research Methods}

Methodologically, the study was built up from the position of identifying the significant shortcomings of the judicial form of protecting the labour rights of the individual, including from the point of view of assessing the accessibility of judicial procedures, ensuring effective mechanisms for protecting the rights of workers. The adversarial form of the civil procedure subjected to critical analysis, does not take into

Issue 33, pp. 670-687; D. Valeev, R. Sitdikov, R. Sitdikova, A. Gabidullina, “A mediation agreement in labour relations. Russia and Italy", Journal of Organizational Culture, Communications and Conflict, 2016, Issue 20, pp. 24-28; W. Zhuang, F. Chen, "Mediate first: The revival of mediation in labour dispute resolution in China", China Quarterly, 2015, Issue 222, pp. 380-402.

${ }^{4}$ M. A. T. Nyenti, "Reforming the south African social security adjudication system: Innovative experiences from South African non-social security jurisdictions", Potchefstroom Electronic Law Journal, 2016, Issue 19; C. Yanyuan, B. Darimont, “Comparative Research on Social Security Dispute Disposal System between Germany and China", Journal of Beijing Administrative College, 2005, Issue2; M. Langford, "The justiciability of social rights: From practice to theory", Social rights jurisprudence: emerging trends in international and comparative law, 2008, Issue 3, pp. 43-45; B. G. Ramcharan, Judicial protection of economic, social and cultural rights: cases and materials, Martinus Nijhoff Publishers, 2005; R. Arango, Realizing Constitutional Social Rights Through Judicial Protection, 2016.

5 A.J.S. Colvin, Conflict and employment relations in the individual rights era, 2016, doi:10.1108/S0742-618620160000022002; B. Walker, R.T. Hamilton, “Disputes between representatives and labour rights: what does work and what doesn't?", Journal of Industrial Relations, 2012, Issue 54, pp. 596-611; A. Hyde, The idea of the idea of labour law: A parable, 2011, doi:10.1093/acprof:oso/9780199693610.003.0007. 
account the employee's limited ability to provide evidence in a dispute with the employer, as well as fundamentally different opportunities for employers in access to qualified legal assistance, and therefore in access to justice.

Methodologically, the research was carried out using traditional methods inherent in legal science: formal legal (dogmatic), sociological and legal, the legal modelling method, as well as the critical legal method of legal knowledge.

A formal legal method makes it possible, exclusively within the framework of sources of law, without distraction by other social objects, to analyse the current state of legal regulation of the judicial form of protection of labour rights, determine the quality of legal norms, and formulate conclusions.

The use of the sociological and legal method makes it possible to collect and process court decisions on labour disputes, identifying common claims and typical mistakes in law enforcement, comparing judicial practice in courts of all instances.

The critical legal method of legal knowledge applied when justifying the required changes in the material and procedural legislation, as when analyzing the Regulatory Resolution No. 9 "On the Particular Issues of Legislation's Application by Courts in resolving Labour Disputes" dated October 6, 2017 (hereinafter - RR) is the most important source of regulation of labour relations. Naturally, RR does not directly regulate individual or collective labour relations, but the provisions of $\mathrm{RR}$ are a kind of benchmark, a standard for the development of labour and relations directly related to them, the lawful behavior of their subjects. And the most important function of the RR is to provide clarifications on the issues of judicial practice to resolve labour disputes in conciliation commissions and courts. RR acquires a particular significance in the context of instability of labour legislation, the presence of many gaps and contradictions in it, as well as in the circumstances of a decrease in the role of normative regulation of hired labour, when the liberalization of legal regulation of employment that took place five years ago was not supported by an increase in the level of legal culture, strengthening of the principle of sustainability and the legality of contractual regulation of labour relations. 
The critical legal method ensures the identification of the shortcomings of the current edition of the RR: the lack of a proper structure, which would in fact reflect the clarification of issues of judicial practice in various categories of labour disputes. The content of the RR's clarifications is not sufficient for the correct resolution of typical labour disputes: some conclusions of the RR are in conflict with the provisions of the Labour Code.

Methodology for collecting primary (initial) information:

- desk research: law enforcement practice, reports related to the functioning in Kazakhstan of the judicial form of protection of labour rights of the individual, analysis of documents and statistical data of courts, summary of examples from judicial practice using the monitoring method, as well as examples of best foreign practice in the work of specialized courts, international universal standards of access to justice in labour disputes;

- content analysis of publications in special groups created on the social network Facebook by judges, lawyers, judicial representatives on improving the organization of the judicial system, expanding access to justice, discussing practical and theoretical problems of considering and resolving labour disputes, as well as comments and publications on the Taldau forum specially created by the Supreme Court (https://office.sud.kz/forumTaldau/ index.xhtml).

We have identified, but not limited ourselves to, the following sources of collection of primary information:

- special electronic services of the Supreme Court of the Republic of Kazakhstan (Judicial Office https://office.sud.kz/, Bank of Judicial Acts https://sud.gov.kz/rus/court-acts), which provide an opportunity to remotely search for court documents and cases; information on the results of sociological surveys and assessments of the activities of the courts of the Republic of Kazakhstan;

- statistical data on the consideration of civil cases by the Supreme Court (http://sud.gov.kz/rus/content/statisticheskie-dannyeo-rassmotrenii-grazhdanskih-del); reports on the work of the courts of the first instance for the consideration of civil cases, presented on the information service of the Committee on Legal Sta- 
tistics and Special Records of the General Prosecutor's Office of Kazakhstan (qamqor.gov.kz);

- materials and recommendations of conferences and other dispute platforms organized by the Supreme Court, as well as materials from special editions of the Supreme Court;

- the results of previous studies on related issues related to the subject of this article, including those published in peer-reviewed scientific journals, an overview of the foreign practice of the functioning of special courts considering labour disputes, ILO instruments, OECD special reviews.

\section{Review of Judicial Practice in Labour Disputes}

The summary of judicial practice made it possible to distinguish the following types of labour disputes in legal relations, from which they arise. Labour disputes:

- arising from the violation of labour relations;

- arising from the violation of employment relations with this employer;

- arising from the violation of social-partnering relations;

- arising from the violation of relations on the participation of employees (their representative bodies) in the management of the organization;

- arising from the violation of relations on vocational training, retraining, and advanced training with this employer;

- arising from a violation of relations on material responsibility of the parties to the employment contract;

- arising from the violation of relations for supervision and control over the observance of labour legislation;

- arising from the violation of relations for the resolution of labour disputes;

- arising from the violation of relations on compulsory social insurance, social security.

In accordance with the Labour Code, the main ways to protect labour rights are:

- self-protection by employees of labour rights; 
- protection of the labour rights of workers by their representatives (trade unions);

- state supervision and control over the observance of labour legislation (local labour inspection body, prosecutor's office);

- appeal to special bodies considering labour disputes;

- judicial protection.

Since the judicial form has priority in relation to other forms of restoration of violated rights, owing to the constitutional right of everyone to judicial protection of their rights and freedoms, then in determining the various forms of protection of rights, the judicial form plays a leading role as universal, historically established, thoroughly regulated by the norms of civil procedural law. It provides reliable guarantees for the correct application of the law. Despite the introduction in Kazakhstan since 2016 of the practice of mandatory pre-trial settlement of individual disputes by conciliation commissions created at workplaces, the number of appeals to the court has not fundamentally decreased. In the period from 2016 to 2019, an average of 8400-8200 claims on labour disputes was received by the courts annually, civil proceedings were initiated on average in 7200 claims, and about $4000-4400$ claims were considered and adjudicated annually. ${ }^{6}$

The global COVID-19 pandemic did not affect the number of appeals to the courts for the consideration of labour disputes. In 2020, Kazakhstani courts received about 7,200 claims for violations of labour rights, of which about $30 \%$ are claims for the payment of wages, and $10 \%$ are claims for reinstatement at work. ${ }^{7}$

${ }^{6}$ Z. Khamzina, Y. Buribayev, P. Almaganbetov, A. Tazhmagambet, Z. Samaldykova, N. Apakhayev, "Labour disputes in Kazakhstan: Results of legal regulation and future prospects", Journal of Legal, Ethical and Regulatory, 2020, Issue 23, pp. 1-14; Reports on the consideration of civil cases by the courts of first instance. Statistical data on the consideration of civil cases of the Supreme Court of the Republic of Kazakhstan, available at: http://sud.gov. $\mathrm{kz} / \mathrm{rus} / \mathrm{content} /$ statisticheskie-dannye-o-rassmotrenii-grazhdanskih-del [last accessed 15.04.2021]; Reports on the work of the courts of first instance in civil cases, information service of the Committee for Legal Statistics and Special Accounting of the General Prosecutor's Office of the Republic of Kazakhstan, available at: https: //qamqor.gov.kz [last accessed 15.04.2021].

7 Reports on the consideration of civil cases by the courts of first instance. Statistical data on the consideration of civil cases of the Supreme Court of the Republic of Kazakhstan, available at: http://sud.gov.kz/rus/content/statisticheskie-dannye-o-rassmotrenii-grazhdanskih-del [last accessed 15.04.2021]; Reports on the work of the courts of first instance in 
An analysis of judicial practice shows that, in general, disputes of this category are resolved correctly. The decisions made mainly meet the requirements of civil procedural legislation; the courts correctly apply the substantive law, and take into account the explanations of the Supreme Court of Kazakhstan, the Labour Code, and the legal position on specific disputes expressed by the Supreme Court in reviews of judicial practice.

At the same time, there are also mistakes. In 2019, the appellate courts cancelled and changed about $30 \%$ of the total number of appealed decisions. It should be noted that some mistakes are made from year to year, which indicates that judges do not carefully follow the established judicial practice. The subject of proof is not always correctly determined, and the circumstances that are important for the case are not fully established. Errors are also tolerated in the application and interpretation of substantive law. The analysis showed that cases when considering whether it is necessary to be guided by special legislation, since, by virtue of a direct instruction contained in the law, the norms of labour law cannot be applied when considering disputes that have arisen, have appeared in judicial practice. In resolving these disputes, judges are guided by the Labour Code of Kazakhstan.

Speaking about the quality of court decisions rendered by judges of first instance, it should be said that often court judgments are "cluttered" with a listing of case materials, and the explanations of the parties and witnesses, and the text of the statement of claim are fully provided. At the same time, as a rule, in such decisions there is practically no reasoning in the conclusions of the court on the stated requirements. And this is not only a problem of decisions made in labour disputes. Errors are tolerated when determining the jurisdiction of labour disputes, and when exercising the plaintiff's right to choose a jurisdiction at his own discretion, as well as when applying the statute of limitations for going to court.

Courts rarely use the provisions of ratified international acts guaranteeing the labour rights of the individual when motivating their decisions. So, in 2019, the courts issued 179 decisions using the Internation-

civil cases, information service of the Committee for Legal Statistics and Special Accounting of the General Prosecutor's Office of the Republic of Kazakhstan, available at: https: //qamqor.gov. $\mathrm{kz}$ [last accessed 15.04.2021]. 
al Covenant on Economic, Social and Cultural Rights, and 22 - using the International Convention on Rights of Persons with Disabilities. ${ }^{8}$ At same time, the courts are the final link in the implementation of international standards for the protection of human rights. ${ }^{9}$

\section{THE SHORTCOMINGS OF THE JUdiCIAL SYSTEM THAT HINDER THE EFfECTIVE PROTECTION OF LABOUR RIGHTS}

The question of the effectiveness of mechanisms for the protection of labour rights is closely related to ensuring access to justice. Access to justice is at the heart of growing of inclusion growth and plays a central role in ensuring well-being and sustainable development. Effective access to justice helps resolve disputes that are at the heart of people's lives, promotes government accountability, and gives people and businesses confidence to enforce contracts. Access to justice refers to the ability of people to seek a fair solution to judicial problems (an issue that raises legal questions) and to protect their rights in accordance with the human rights standards; if necessary, through impartial formal or informal institutions and with appropriate legal support. ${ }^{10}$

A reliable system of justice also supports the rule of law, good governance, and efforts to address issues of inequality and problems of development. There is growing evidence of a complex relationship between unequal access to justice and broader socio-economic gaps. Failure to access justice can be both a result and a cause of disadvantage

${ }^{8}$ Reports on the consideration of civil cases by the courts of first instance. Statistical data on the consideration of civil cases of the Supreme Court of the Republic of Kazakhstan, available at: http://sud.gov.kz/rus/content/statisticheskie-dannye-o-rassmotrenii-grazhdanskih-del [last accessed 15.04.2021]; Reports on the work of the courts of first instance in civil cases, information service of the Committee for Legal Statistics and Special Accounting of the General Prosecutor's Office of the Republic of Kazakhstan, available at: https: //qamqor.gov. $\mathrm{kz}$ [last accessed 15.04.2021].

${ }^{9}$ M.A. Sarsembayev, International standards for the protection of human rights and their implementation in court decisions, 2016, p. 142, available at: https://www.gcedclearinghouse.org/sites/default/files/resources/190256rus.pdf [last accessed 15.04.2021].

${ }^{10}$ OECD/Open Society Foundations Legal Needs Surveys and Access to Justice, OECD Publishing, 2019, https://doi.org/10.1787/g2g9a36c-en [last accessed 15.04.2021]. 
and poverty. Unmet needs for justice can lead to social, physical, and mental problems, reduced productivity, and reduced access to economic opportunities, education, and employment. Unresolved legal problems do not allow people, businesses, and society as a whole to reach their full potential. ${ }^{11}$

The general shortcomings of the judicial system that hinder the effective protection of the labour rights of citizens are the high workload of courts and restrictions on access to justice. However, this general argument, which applies to all areas of the administration of justice, is "superimposed" on the following facts.

Labour laws are little developed from the standpoint of the legal science of Kazakhstan. A review of dissertations defended for academic degrees in Kazakhstan for the period from 1992 to $2020^{12}$ allows us to draw the following conclusions. In total, in all branches of science, 26915 dissertations were defended at the beginning of April 2020, of which on the legal problems of the sphere of wage labour, employment, about 40 dissertations were defended during this period. In turn, about 30 of them are candidate dissertations on labour law, 5 are doctoral studies; as well as $5 \mathrm{PhD}$ dissertations - on the problems of employment, hired labour. That is, the academic and legal support for the problems of hired labour in Kazakhstan is at a minimum level.

The fact that representatives of legal science do not show interest in the subject of how legislative regulation of employment directly affects the quality of the educational process, is confirmed by the absence, with some exceptions, of special literature and reviews. At the same time, the branches of labour law have very complex specifics. This area is one of most "sensitive" for a person, and it is common here for most vulnerable groups of the population that have neither material nor physical resources to fall into the orbit of legal proceedings. The above aspects require the state to pay more attention to this area of justice, create special mechanisms for restoring violated rights, and protect vital interests. The following factor follows from the above circumstances.

11 Equal Access to Justice for Inclusive Growth: Putting People at the Centre, OECD Publishing, 2019, https://doi.org/10.1787/597f5b7f-en.

12 National Centre for State Scientific and Technical Expertise. National resources. Dissertation, available at: http://nauka.kz/page.php?page_id=107\&lang=1 [last accessed 15.04.2021]. 
The mechanism for ensuring the reconciliation of interests is an effective judicial system, which must be "tuned" to the special subject composition of labour legal relations. It should differentiate between the principles of civil and labour contracts; provide a special approach to the settlement of labour disputes, taking into account the vital necessity for citizens to participate in hired labour and receive remuneration; take into account the risk for citizens of loss of life and health in labour relations if the employer does not comply with labour protection measures; take into account the impossibility of restoring the original position of the parties when terminating the employment contract.

Wage labour is characterized by the fact that a person "sells, transfers" to the employer the most expensive things that he/she has, which are knowledge, skills, and time. We are dealing with an animate subject of wage labour - the labour force, which determines the specifics of the branch of labour law, its meaning and content, since wage labour requires a special approach to legal regulation, considering that the health and life of the employee must be fully protected in labour relations. Wage labour is a non-recoverable category that cannot be returned in kind when terminating the employment contract: if the employment contract is declared invalid or illegal, it is impossible to bring the parties to the employment contract to their original position. The sphere of wage labour and the legal norms regulating it are not limited only to labour relations, also included are such areas of public life as employment, professional training and professional development, social partnership, and control activities in the sphere of employment carried out by specialized competent officials and bodies.

The Supreme Court does not have specialists in labour and social security law who can prepare and provide high-quality explanations of legislation and law enforcement in this area of public relations. This conclusion is based on an analysis of the results of the summary of the practice of applying the legislation by the courts, presented by the Supreme Court of the Republic of Kazakhstan (SC) in the regulatory Resolution No. 9 "On Particular Issues of the Application of Legislation by the Courts in resolving Labour Disputes" dated October 6, 2017 (hereinafter - RR). The RR is the most important source of the regulation of labour relations in terms of the content of Paragraph 1, Article 2 of the LC, which stipulates that the labour legislation of the Republic of Kazakh- 
stan is based on the Constitution and consists of the LC, laws, and other regulatory legal acts, which means that the national labour legislation includes the considered RR. Naturally, the RR does not directly regulate individual or collective labour relations, but the provisions of the RR are a kind of reference point, a standard for the development of labour and directly related relations, and the lawful behavior of their subjects. And the most important function of the RR is to provide explanations on the issues of judicial practice for the settlement of labour disputes in conciliation committees and the courts. The RR is particularly important in the conditions of instability of labour legislation, the presence of many gaps and contradictions in it, as well as in circumstances where the role of normative regulation of wage labour has been reduced, and when the past liberalization of legal regulation of employment has not been supported by an increase in the level of legal culture, strengthening the principle of stability and legality of contractual regulation of labour relations.

Analysis of the RR content makes it possible to verify its insufficient elaboration, many contradictions and outdated provisions, a large volume of citations of the LC rules, and the limitations and futility of the wording of certain paragraphs. Also, the inventory item has the following disadvantages:

- Limited explanation of the procedural procedure for applying to the court and considering cases arising from employment and directly concerned relations;

- In fact, there is no explanation of the most important aspects of labour disputes;

The inventory item does not have a coherent structure that reflects the dynamics of labour relations. The current version of the RR does not meet the requirements for the quality level of the normative legal act and does not have a proper structure that would actually reflect explanations of judicial practice in various categories of labour disputes. The content of the RR explanations is not sufficient for the correct resolution of typical labour disputes, and some of the RR conclusions contradict the provisions of the LC. ${ }^{13}$

${ }^{13}$ Zh.A. Khamzina, "Questions as to the quality of the regulatory resolution "On some issues of the application of legislation by the courts in resolving labour disputes", 
Besides, the research highlights the following disadvantages of labour disputes in Kazakhstan courts: lack of a clear hierarchy of the sources of the labour laws: the law, social partnership agreement, collective contract, labour contract, non-recognition of CPC agreements as normative sources of law; and contradictions of court decisions on labour legislation. ${ }^{14}$

In aggregate, we believe that the above theses should be considered in the establishment of specialized labour courts in Kazakhstan that ensure the protection and restoration of the most important rights of individuals to work and social protection, providing for living conditions that ensure human dignity, equality, and a minimum level of social guarantees. The creation of labour courts in the system of general jurisdiction would bring the consideration of disputes arising from labour, directly related to them, as well as social and security relations to a qualitatively new level, increase its effectiveness, and contribute to achieving uniformity of law enforcement in these areas throughout the country.

\section{IMPROVING THE JUDICIAL PROTECTION OF INDIVIDUAL LABOUR RIGHTS THROUGH THE ORGANIZATION of SPECIALIZED COURTS}

Judicial protection is the most common way to protect labour rights and the most effective in terms of consequences. However, it should be noted that a large number of applications to the court for the protection of labour rights shows, firstly, the unsatisfactory resolution of the dispute in other ways that are closest to the employee.

Currently, in Kazakhstan, the courts of general jurisdiction are fully subject to labour disputes. The system of judicial review and resolution of a labour dispute in our country has all the makings of differen-

2019, available at: https://online.zakon.kz/Document/?doc_id=37456619\#pos=5;-106 [last accessed 15.04.2021].

${ }^{14}$ M.Kh. Khassenov, "What is wrong with judicial practice in labour disputes?", 2020, available at: https://www.zakon.kz/5010181-chto-ne-tak-s-sudebnoy-praktikoy-po.html [last accessed 15.04.2021]. 
tiating judicial collegiums depending on the nature of the dispute, as is done in certain foreign countries (Germany, Norway, Switzerland, and Belgium). Many legal systems have specialist work courts with jurisdiction over individual employment disputes or collective work disputes or both. ${ }^{15}$

Owing to such negative features inherent in the system of judicial review and resolution of labour disputes in Kazakhstan, such as the congestion of courts of general jurisdiction, and non-compliance with the deadlines set in the Labour Code and the Civil Procedure Code for the consideration and resolution of labour disputes, the research team believes that it is reasonable at the present time to gradually reform the existing system of labour dispute resolution. At the first stage, it is necessary to legislate for the allocation in both district courts and regional courts, of panels for the consideration of labour disputes, which will ensure the unity of judicial practice. The second stage should be the direct creation of labour courts - the first and appeal instances.

The proposed separation of special labour courts from the courts of general jurisdiction will make it possible to legitimize the specialization of judges of general jurisdiction that has already developed in practice some judges usually deal only with family cases, others only with civil cases, and others with labour disputes. Such specialization is quite effective owing to the need to take into account the important specifics of a particular category of cases, the need for a judge to have deep special knowledge, which is quite difficult to achieve in all areas at the same time. In addition, specialization within the courts of general jurisdiction and the allocation of special judges for labour disputes will significantly relieve the rest of the judges involved in other types of disputes, which is important, given the enormous burden on judges of general jurisdiction in our country. The consequence of this will be a reduction in the time of consideration of cases in court.

We believe that the specialization of courts is due to a number of reasons: first, their creation will contribute to the strengthening of the judicial system; second, the consideration and resolution of a specific category of cases ensures the higher professionalism of judges, since the

15 A.C.L. Davies, "The court of justice as a labour court", Cambridge Yearbook of European Legal Studies, 2012, Issue 14, pp. 145-175. 
lack of specialization of judges does not allow the courts to take into account the specifics of the dispute; third, the courts of special jurisdiction will ensure the speed of judicial proceedings.

Labour disputes have a number of features that can influence the judicial process in resolving them, which requires a more thorough, more professional approach to them. In the conditions of Kazakhstan, at least several reasons and facts determine the active promotion of the idea of creating a specialized court for labour and social disputes.

This is a highly important, and in some cases vital necessity, for a person to observe and fulfill social and labour guarantees, in view of the "weakness" of the employee in labour relations with the employer, as well as a vulnerable position of persons receiving various types of social security.

Wage labour is characterized by the fact that a person "sells, transfers" to the employer the most precious thing that he has: his knowledge, skills, work skills, and his time. We are dealing with the animate object of the wage labour force, which determines the specifics of the branch of labour law, its meaning and content, since wage labour requires a special approach in legal regulation, taking into account the fact that the health and life of the employee must be fully protected in labour relations. Wage labour is a category of the non-recoverable, which could not return in kind in the event of termination of the employment contract: if the employment contract is declared invalid, and/ or illegal, it is impossible to bring the parties to the employment contract back to their original position.

It is impossible to consider wage labour only as a commodity in the labour market since it is not separable from the person's personality. An employee in an employment relationship is a dependent or weaker party relative to the employer. At the same time, employees act as applicants in court with claims for the restoration of violated social and labour rights.

The main role of labour law is that it coordinates the interests of society and the state, as well as employees and employers in the field of employment. One of the mechanisms for ensuring such a reconciliation of interests is an effective judicial system, which should be "adjusted" to the special subject composition of labour relations; it should differentiate between the principles of civil and labour contracts; provide a spe- 
cial approach to the settlement of labour disputes, taking into account the vital need for citizens to participate in wage labour and receive remuneration; take into account the risk for citizens of loss of life and health in labour relations if the employer does not comply with labour protection measures; take into account the impossibility of restoring the original position of the parties (bringing the parties to the original position) when terminating the employment contract.

Together, the above theses, we believe, should take into account in the establishment of specialized social and labour courts in Kazakhstan, ensuring the protection and restoration of the most important rights of the individual to work and social protection, and ensuring living conditions that ensure human dignity, equality, and a minimum level of social guarantees. The creation of social and labour courts in the system of general jurisdiction would bring the consideration of disputes to a qualitatively new level, increase efficiency, and contribute to achieving uniformity of law enforcement in these areas throughout the country.

\section{RECOMMENDATIONS FOR IMPROVING THE EFFICIENCY OF THE NON-JUDICIAL FORM OF PROTECTION OF LABOUR RIGHTS}

The creation of courts for labour disputes, in our opinion, is not the only approach to solving the problems of effective resolution and prevention of relevant conflicts. At the same time, this direction requires in-depth scientific and practical analysis and assessment from the standpoint of alternative ways of protecting the labour rights of the individual.

In recent decades, the state has promoted the idea of forming structures for the pre-trial consideration of individual labour disputes. Research considers alternative dispute resolution processes as a way to avoid costly and lengthy litigation and in some circumstances it may improve access to justice for individuals. ${ }^{16}$ The main forms of alternative dispute resolution (hereinafter - ADR) in Kazakhstan are currently

${ }^{16}$ T. MacDermott, J. Riley, "Alternative dispute resolution and individual workplace rights: The evolving role of Fair Work Australia", Journal of Industrial Relations, 2011, Issue 53, pp. 718-732. 
conciliation commissions for individual labour disputes, while for collective labour disputes, the ADR forms are conciliation commission, labour arbitration, and mediation. It is also possible to resolve a collective labour dispute by conducting direct negotiations. However, owing to the LC classification of labour disputes into individual and collective, there is a situation when out-of-court settlement of individual labour disputes is possible only in conciliation commissions and through mediation, while for collective labour disputes a closed list of ways to resolve them is established. In the view of the co-authors of this study, a single and at the same time open list of ways to resolve labour disputes should be provided for all.

Another way to resolve labour disputes with the participation of an intermediary is the mediation procedure, the regulation of which currently requires changes.

The combined analysis allows us to identify conditions in Kazakhstan that currently do not allow expanding the application of mediation to labour disputes.

First, since the parties to the labour dispute have the right to determine whether a mediator has imposed any decision on the dispute, and the degree of compulsory execution of such decisions, the employer can always ignore the result, which is inappropriate for him/her, and the employee will have to apply to court.

Second, the costs associated with conducting mediation procedures are currently several times higher than the costs associated with applying to the court for protection of the violated right.

Third, the legislator has established insufficient requirements for the qualification of mediators in the field of labour law.

Fourthly, there are general problems with the work of mediators without industry affiliation such as: the low awareness of the population about mediation procedures, and low confidence in them, as well as the lack of state control over the quality of training of professional mediators by relevant organizations; standards of appropriate training; state coordination and regulation of many different organizations of mediators that do not have a common center and conditions for interaction. It may be necessary to consider the use of judicial mediation to ensure that this procedure is free of charge to the parties to the labour dispute by financing it from the state budget. We recommend that the 
Ministry of Labour and Social Protection include in its functions maintaining a list of recommended mediators, resolving labour disputes directly on the law, as well as guidelines for the resolution of labour disputes through extrajudicial procedures.

Mediation is designed to qualitatively improve the implementation of the right of the parties to an employment contract to resolve the conflict through appropriate and informal procedural choices. However, the rhetoric is ahead of the reality: our current legal process and practice are largely weighted in favour of a single adversarial structure-litigation, although judicial procedures are not always the most effective way to solve legal problems. ${ }^{17}$ The mediation method of settlement of labour disputes has some advantages compared to state proceedings, such as: no problems with jurisdiction and missing the deadline for applying for a dispute resolution; speed in resolving the conflict (unlike the court, the mediator does not need to obtain evidence in the case, appoint experts, call witnesses to testify, etc.); reduction of the risks of non-compliance with the decision agreed by the parties, since it is made voluntarily and does not contain elements of coercion; confidentiality of information that appears in the negotiation process; maintaining positive relations between the disputants, restoring a favorable microclimate in the labour group; reaching a compromise without forceful pressure on the subjects of labour relations; reducing the costs of the parties to the dispute and the state. ${ }^{18}$ However, the presumption that the courts are the principal forum for dispute resolution continues to be eroded. Alternative forms of dispute resolution (ADR), including agreement-based ADR (such as mediation and conciliation) and adjudicative ADR (such as arbitration), continue to proliferate and are increasingly institutionalized, leading to their characterization as 'appropriate' or 'proportionate' dispute resolution. ${ }^{19}$

${ }^{17}$ R. Álvarez, "The role of mediation in the resolution of employment disputes. [E] papel de la mediaciónen la resolución del conflicto individual de trabajo]", Trabajo y Derecho, 2015, Issue 2.

18 S. Yu. Golovina, "Problems of using mediation in resolving labour disputes", Russian Law Journal, 2013, Issue 6, pp. 119-126.

${ }^{19}$ L. McGregor, "Alternative dispute resolution and human rights: Developing a rights-based approach through the ECHR", European Journal of International Law, 2015, Issue 26, pp. 607-634. 
In general, the alternative resolution of labour disputes in Kazakhstan needs to improve its coherence and adapt various mechanisms appropriate to the needs of participants in the relevant dispute relations. There is a need to develop a comprehensive strategy for additional forms of dispute resolution through mediation, pre-trial reconciliation, ombudsmen, arbitration, and other mechanisms. It is necessary to expand mediation in all areas of the labour sphere, to strengthen the potential and status of subjects of the alternative dispute resolution system, and to increase the awareness of citizens and legal entities about their potential. The issue of improving the efficiency of courts in labour disputes owing to greater clarity of jurisdiction and meritocracy of decision-making is relevant.

Summarizing the experience of conducting pre-trial settlement of individual labour disputes in individual member states of the OECD (Lithuania, Estonia, Latvian, Ireland, Czech Republic, and Italy), we can state that we have not identified in the legislation of any OECD country the shortcomings that the activities of the conciliation commission in Kazakhstan have. These defects are as follows: the lack of professionalism in the composition and work of the Kazakhstan conciliation commission; in OECD states, the relevant entities act exclusively on a professional basis, including with the requirements for the qualifications of members of various commissions, tribunals, and their presidents. Second, in all the OECD states where pre-trial conciliation bodies operate, there are no possibilities for them to rely on the employer in any way, and the Kazakhstan conciliation commission is organizationally, morally, and materially subordinate to the will of the employer. Third, in Kazakhstan, the conciliation commission is not a permanent body, and therefore does not correspond to the conditions of the reviewed OECD states; if the conciliation entities are not permanent, then in the OECD states, the right to directly file a claim to the court is provided, bypassing the pre-trial procedure. Fourth is non-involvement of Kazakhstani state bodies in the procedures of functioning of the conciliation commissions, which operate on their own; The State Labour Inspectorate and the Ministry of Labour and Social Protection of the RK population do not interfere in the work of commissions, do not control their work, the decisions made, or the composition and professionalism of the members. 
We recognize that the arguments about the erroneousness of introducing mandatory pre-trial consideration of an individual labour dispute in a conciliation commission in Kazakhstan are justified. The obligatory nature of this stage of resolving a dispute in conciliation commissions deprives the disputing parties of the right to choose other alternative methods of resolving disputes and opposes the right to judicial protection guaranteed by the Constitution. In the course of the analysis of the practice of applying labour legislation, which regulates the procedure for considering appeals to conciliation commissions and civil courts, we identified circumstances that impede the full consideration and resolution of individual labour disputes, leading to the conclusion that it is necessary to reform the pre-trial procedure for resolving a dispute. In particular, we propose to reform the procedure for an employee's appeal to conciliation commissions, to introduce new methods of alternative dispute resolution.

The defectiveness of the pre-trial dispute settlement system in Kazakhstan has a most important drawback for the economy, which is that it unreasonably delays the resolution of individual conflicts, according to research by McGregor ${ }^{20}$ Gianfreda/Vallanti, ${ }^{21}$ and Knol Radoja. ${ }^{22}$ The impact of delays in labour litigation is significant on employment. Delays in labour courts are found to reduce employment and increase the inactivity of categories of workers, that is, women, youth, and lowskilled persons; they also reduce the likelihood of gaining access to permanent work and increase the frequency of long-term unemployment for the same groups of workers. For Kazakhstan, which faces a high level of latent unemployment, this problem is especially important, since it has been created directly by the state power by establishing an imperative procedure for pre-trial consideration of disputes by conciliation commissions.

${ }^{20}$ L. McGregor, "Alternative dispute resolution and human rights: Developing a rights-based approach through the ECHR", European Journal of International Law, 2015, Issue 26, pp. 607-634.

${ }^{21}$ G. Gianfreda, G. Vallanti, "Labour courts and firing costs: The labor-market effects of trial delays", Industrial Relations, 2020, Issue 59, pp. 40-84.

${ }^{22} \mathrm{~K}$. Knol Radoja, "The right of access to the court in individual labour disputes", Balkan Social Science Review, 2019, Issue 13, pp. 7-25. 


\section{CONCLUSIONS}

The study contributes to a legal dialogue between representatives of theoretical legal science and representatives of the justice system, practicing lawyers interested in improving the national judicial practice. The recommendations and conclusions drawn from the study stimulate discussion on ways to improve the justice system, which operates in accordance with universal human rights standards in the labour sphere.

The theoretical results of the research will generalize and supplement the existing knowledge with the forms and means of protecting labour rights. The practical application of research results consists in the development of a number of proposals on amendments and additions to the Labour Code, the Code of Civil Procedure, and other regulatory legal acts, as well as in the preparation of proposals for clarification by the Supreme Court of the Kazakhstan on the implementation of restorative justice in judicial practice in field of labour rights of the individual.

\section{ACKNOWLEDGMENTS}

The Science Committee of the Ministry of Education and Science of the Republic of Kazakhstan (Grant No. fund this research AP09259109). 